\title{
A Comparative Analysis of the Aspects and Costs of Emergency Department Visits of Syrian Refugees with Turkish People and Former Refugees (Afghan People)
}

\section{Suriyeli Mültecilerin Acil Servis Başvuru Özelliklerinin ve Maliyetlerinin Türk Halkı ve Eski Mülteciler (Afgan Halkı) ile Karşılaştırmalı İncelenmesi}

\author{
[DTufan Alatlı' \\ 'Balikesir University Faculty of Medicine, Emergency Department, Balıkesir, Turkey
}

\begin{abstract}
Aim: Compare the emergency department (ED) use characteristics of old and new refugees and the local people and to investigate whether it brings a different financial burden on the economy of the country.

Material and Method: Syrian, Afghan and Turkish patients who presented to the emergency department between January 1, 2016 and December 31, 2019 were randomly assigned to groups of 1000 people. The data were analyzed retrospectively.

Results: Syrian patients presented to ED with simpler etiologies 1.573 times more (Triage 4-5) compared to Turkish patients $(p=0.009)$. The rate of visits by females was higher in those with triage 1-2-3 than those with triage $4-5(p=0.001)$. There was no difference between during-working-hours or outside-workinghours visits of those with triage 1-2-3. The average per capita cost of Turkish patients was found to be $109.60 \pm 73.36$ Turkish Liras (TL), while it was between $96.20 \pm 35.61$ and $95.24 \pm 28.24$ TL for Syrian and Afghan patients. No difference was found in terms of per capita costs between nationalities $(p=0.766)$.

Conclusion: In order to reduce burden and costs in EDs, Refugees should be trained about the health system after they are admitted to the country, health literacy training programs should be planned for individuals in society from a young age, primary healthcare services should be used more effectively.
\end{abstract}

Keywords: Cost, emergency department, refugee
Öz

Amaç: Eski ve yeni göçmenler ile yerli halkın Acil servis kullanım özelliklerini karşılaştırarak ülke ekonomisine farklı bir mali yük getirip getirmediğini incelemektir.

Gereç ve Yöntem: 01.01.2016- 31.12.2019 arasında Acil Servise başvuran Suriyeli, Afgan ve Türk hastalar rastgele örnekleme yoluyla 1000'er kişilik gruplara ayrıldı. Veriler retrospektif olarak incelendi.

Bulgular: Suriyeli hastalar Türk hastalara kıyasla AS'e 1.573 kat daha fazla daha basit etyolojiler (Triaj 4-5) ile başvurmakta olduğu görülmüştür ( $p=0.009$ ). Triajı 1-2-3 olanlarda kadın başvuru oranının Triajı 4-5 olanlara kıyasla daha yüksek olduğu saptanmıştır ( $p=0.001)$. Triaj 1-2-3 olanların mesai içi veya dışı başvuruları arasında farklıık

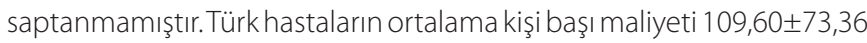
TL olarak saptanmıştır. Suriyeli ve Afgan hastaların ortalama kişi başı

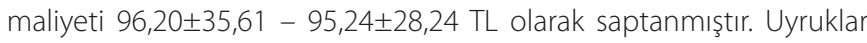
arasında kişi başı maliyetleri karşılaştııılığında fark saptanmamıştır $(p=0.766)$.

Sonuç: Mülteciler ülkeye kabul edildikten sonra sağlık sistemi hakkında eğitim verilmesi, daha küçük yaşlardan itibaren topluma sağlık okuryazarlığı eğitimleri planlaması, birinci basamak sağlık hizmetlerinin daha etkili kullanılmasının sağlanması acil servislerde gereksiz yoğunluğun ve maliyetin azaltılması için uygun olacaktır.

Anahtar Kelimeler: Maliyet, acil servis, mülteci 


\section{INTRODUCTION}

The phenomenon of forced migration is a general term that refers to hungry, injured, and abused men, women, and children abandoning their homelands due to wars and oppression. ${ }^{[1]}$ A refugee, on the other hand, is defined as a person who has been declared persona non grata or is unlikely to return to their own country due to a strong fear of persecution because of affiliation to a particular social group, political view, religion, or ethnic origin. ${ }^{[2]}$ According to the United Nations High Commissioner for Refugees, there are approximately 25.4 million refugees worldwide. ${ }^{[3]}$

The number of Syrian refugees coming to Turkey has gradually been increasing since the Syrian civil war when the largest refugee crisis broke out after World War II. ${ }^{[4]}$ Almost, 64\% of the Syrian refugee population is sheltered within Turkish territories. The total size of refugees in Turkey is more than 3,600,000 people..$^{[5]}$

The most important feature of emergency department (ED) is that they work on the basis of 24/7 service. EDs provide treatment to visitors regardless of their income, race, ethnicity, insurance status, or special needs. ${ }^{[6]}$ It is essential to provide the necessary service as soon as possible to patients who need it and to give priority to the most urgent. In our country, where approximately 80 million people live, the total number of ED examinations was shown as 84.5 million in the first 10 months of the year 2017. In the same period, ED examinations made up $28.5 \%$ of the total examinations in all branches. This rate shows that the branch with the highest patient burden among all branches is emergency medicine. ${ }^{[7]}$ Unnecessary ED visits also mean a serious cost. ED's have care barriers due to educational, cultural, communicative, logistic, psychosocial, environmental, or institutional factors and the nature of health problems. ${ }^{[8]}$ Triage scales are important for effective use of the ED and timely intervention to emergency patients.

This study aims to compare the way how ED is utilized by refugees who have recently come to Turkey and has already been in Turkey for a long time (Syrians and Afghans) and the resulting costs with the local population.

\section{MATERIAL AND METHOD}

Syrian, Afghan and Turkish patients who presented to Tokat State Hospital ED January 1, 2016 - December 31, 2019 were determined. During this period, the total visits were as follows: 5,438 Syrian patients, 3,887 Afghan patients, and 1,210,125 Turkish patients. These three groups were divided into equal groups of 1000 people using random sampling method with the help of the SPSS Windows 23.0 software package. The data were analyzed retrospectively. The demographic characteristics of the groups, time of application (within and out of working hours), ED visit triage codes and diagnoses, outcomes and costs were analyzed. The study was carried out with the permission of Tokat State Hospital Ethics Committee (Permission granted: 02.03.2020, Decision no: 04-02).

\section{Statistical Analysis}

The fit of the data to normal distribution was tested with the Shapiro-Wilk test. Student t-test was used to compare normally distributed features in two independent groups, and the Mann-Whitney $U$ test was used to compare nonnormally distributed features in two independent groups. Variables with normal distribution in more than two groups were analyzed with ANOVA and LSD tests. The relationship analysis of categorical variables observed in two independent groups was analyzed with Pearson and Exact Chi-square tests. Nationality, gender, admission time, consultation, and surgery status were analyzed with Multiple LR (Logistic regression) method in the study. Descriptive statistics included mean \pm standard deviation values for numerical variables and numbers and \% values for categorical variables. SPSS Windows version 23.0 software package was used for statistical analysis, and $\mathrm{p}<0.05$ was considered statistically significant.

\section{RESULTS}

The examination of the groups by gender indicated that the rate of male patients presenting to EDs in Afghan (56.5\%) and Syrian patients $(50.7 \%)$ was significantly higher than Turkish patients (48.2\%) $(p=0.001)$. This is shown in Table 1.

\begin{tabular}{|c|c|c|c|c|}
\hline \multirow{2}{*}{\multicolumn{2}{|c|}{ Nationality }} & \multicolumn{2}{|c|}{ Gender } & \multirow{2}{*}{$\mathbf{p}$} \\
\hline & & \multirow{2}{*}{$\begin{array}{c}\text { Male } \\
565\end{array}$} & \multirow{2}{*}{$\begin{array}{c}\text { Female } \\
435\end{array}$} & \\
\hline & $\mathrm{n}$ & & & \multirow{6}{*}{0.001} \\
\hline Atghan & $\%$ & 56.5 & 43.5 & \\
\hline \multirow{2}{*}{ Syrian } & $\mathrm{n}$ & 507 & 493 & \\
\hline & $\%$ & 50.7 & 49.3 & \\
\hline \multirow{2}{*}{ Turkish } & $\mathrm{n}$ & 482 & 518 & \\
\hline & $\%$ & 48.2 & 51.8 & \\
\hline
\end{tabular}

The examination of the mean age of individuals by nationality showed that the mean age of Turkish patients $(29.53 \pm 22.33)$ was statistically significantly higher than both Afghan and Syrian patients $(24.38 \pm 15.33,23.48 \pm 15.35$, respectively) ( $p$ $<0.001)$. The findings are shown in Table 2.

\begin{tabular}{|c|c|c|c|c|c|}
\hline \multirow{2}{*}{ Nationality } & \multirow{2}{*}{$\mathbf{n}$} & \multicolumn{3}{|c|}{ Age (year) } & \multirow{2}{*}{$\mathbf{p}$} \\
\hline & & Mean \pm SD & Min. & Max. & \\
\hline Afghan & 1000 & $24.38 \pm 15.33$ & 1 & 75 & \multirow{4}{*}{$<0.001$} \\
\hline Syrian & 1000 & $23.48 \pm 15.35$ & 0 & 79 & \\
\hline Turkish & 1000 & $29.53 \pm 22.32$ & 0 & 93 & \\
\hline Total & 3000 & $25.79 \pm 18.16$ & 0 & 93 & \\
\hline
\end{tabular}

ED visiting time was classified as "working hours" for hours between 08:00 and16:00 on weekdays, and "out of working hours" for public holidays, weekends, and hours between 
16:00 and 08:00 on weekdays. When a comparison of working hours and out of working hours was made between nationalities, it was observed that the percentage of visits by Turkish citizens during out of working hours $(61.9 \%)$ was higher than that of the refugees. This is shown in Table 3.

\begin{tabular}{|c|c|c|c|c|}
\hline \multicolumn{2}{|c|}{ Nationality } & \multirow{2}{*}{$\begin{array}{c}\text { Out of working hours } \\
476\end{array}$} & \multirow{2}{*}{$\begin{array}{c}\text { Working hours } \\
524\end{array}$} & \multirow{2}{*}{$\mathbf{p}$} \\
\hline \multirow{2}{*}{ Afghan } & $\mathrm{n}$ & & & \\
\hline & $\%$ & 47.6 & 52.4 & \multirow{3}{*}{$<0.001$} \\
\hline \multirow{2}{*}{ Syrian } & $n$ & 450 & 550 & \\
\hline & $\%$ & 45.0 & 55.0 & \\
\hline \multirow{2}{*}{ Turkish } & $\mathrm{n}$ & 619 & 381 & \\
\hline & $\%$ & 61.9 & 38.1 & \\
\hline
\end{tabular}

Visits to ED were classified based on the Australian Triage scale, which is a 5-level triage system. Patients were divided into two groups for statistics: patients with triage level of 1-2-3 as potential emergency cases or emergency cases and patients with triage level of 4-5 as non-emergency cases. According to the triage categories, the majority of the patients (87.8\%) were found to present to ED for non-emergency reasons (Triage 4-5). Statistically significant differences were found between the triage categories of the patients presenting to ED and their gender $(p<0.05)$. As a result of the analysis regarding gender, the rate of female patients (56.4\%) with triage category 1-23 was higher than those with triage category $4-5(p=0.001)$. There was no difference between patients with a triage category of 1-2-3 in terms of visits in working hours or out of working hours. These findings are shown in Table 4.

Table 4. Comparison of Variables by Triage Levels

\begin{tabular}{|c|c|c|c|c|c|c|}
\hline & \multicolumn{4}{|c|}{ Triage } & \multirow{3}{*}{$\mathbf{p}$} \\
\hline & & \multicolumn{2}{|c|}{$1-2-3$} & \multicolumn{2}{|c|}{ 4-5 } & \\
\hline & & $n$ & $\%$ & $\mathrm{n}$ & $\%$ & \\
\hline \multirow{2}{*}{ Gender } & Male & 160 & 43.6 & 1394 & 52.9 & \multirow{2}{*}{0.001} \\
\hline & Female & 207 & 56.4 & 1239 & 47.1 & \\
\hline \multirow[b]{2}{*}{ Visit times } & Working hours & 190 & 51.8 & 1355 & 51.5 & \multirow[b]{2}{*}{0.912} \\
\hline & $\begin{array}{l}\text { Out of working } \\
\text { hours }\end{array}$ & 177 & 48.2 & 1278 & 48.5 & \\
\hline
\end{tabular}

The variables that had a statistical significance at the time when individuals with triage category 4-5 visited ED were modeled with the enter method of multiple logistic regression. Accordingly, nationality was found to be a significant variable on the triage category. It was observed that Syrian citizens were 1.573 times more inclined to present to ED for simpler etiologies (Triage 4-5) compared to Turkish citizens, and this was found to be statistically significant (odds: 1.573 (1.121 2.207) $p=0.009$ ).
The mean cost of Turkish patients per person was found to be 109.60 \pm 73.36 Turkish Liras (TL). The mean cost of Syrian and Afghan refugees per person was $96.20 \pm 35.61$ and $95.24 \pm 28.24 \mathrm{TL}$, respectively. When the per capita costs were compared by nationality, no statistical significance was found $(p=0.766)$. The findings are presented in Table 5 .

\begin{tabular}{|c|c|c|c|c|c|}
\hline \multirow{2}{*}{ Nationality } & \multirow{2}{*}{$\mathbf{n}$} & \multirow{2}{*}{ Mean \pm SD } & \multicolumn{2}{|c|}{ Costs (TL*) } & \multirow{2}{*}{ p } \\
\hline & & & Min. & Max. & \\
\hline Afghan & 1000 & $95.24 \pm 28.24$ & 1 & 3107 & \multirow{4}{*}{0.766} \\
\hline Syrian & 1000 & $96.20 \pm 35.61$ & 0 & 5909 & \\
\hline Turkish & 1000 & $109.60 \pm 73.36$ & 6 & 18197 & \\
\hline Total & 3000 & $100.38 \pm 49.47$ & 0 & 18197 & \\
\hline
\end{tabular}

\section{DISCUSSION}

Gülaçtı et al. ${ }^{[11]}$ (2017) found that the majority of Syrian refugees who presented to EDs were females. Similarly, according to some studies in the literature, females make up the majority of the patients presenting to EDs. ${ }^{[9-13]}$ On the other hand, there are also studies in the literature reporting opposite findings that the majority of patients presenting to EDs are males. ${ }^{[1,15]}$ Our study adds the literature the finding that the majority of Syrian and Afghan refugees presenting to EDs are males, while the majority of the Turkish patients presenting to EDs are female patients. It can be thought that in the refugee groups, males are more involved in social life than females, and therefore they present to EDs more often.

The age range of patients presenting to EDs vary in the literature; yet, the majority of them are young adult patients. For example, Ersel et al. ${ }^{[9]}$ (2006) reported that the majority of patients presenting to EDs were in the 17-39 age group (39.0\%). There are various mean age reports about patients presenting to EDs in the literature, such as 25-44 in Şimşek et al. ${ }^{[10]}$ (2018), 33 in Çevik et al. ${ }^{[12]}(2014)$, and 17-65 (77\%) in Köse et al. ${ }^{[14]}$ (2011). Also, regarding the studies conducted on refugees, Gülaçtı et al. ${ }^{[11]}$ (2017) reported the mean age as 34.6 and Tahirbegolli et al. ${ }^{[16]}$ (2016) as 19. In our study, the mean ages of all our groups were in the third decade and were found to be consistent with the literature. It can be said that the majority of the refugee population who took refuge in our country is the young population.

According to the results of the studies conducted by Köse et al. ${ }^{[14]}$ (2011), Incesu et al. ${ }^{[15]}$ (2016), Tahirbegolli et al. ${ }^{[16]}$ (2016), and Aydın et al. ${ }^{[17]}$ (2010), the rates of presenting to EDs during working hours were $60.5 \%, 55.9 \%$, and $53.3 \%$, respectively, which were reported to be higher compared to non-working hours. Also, Aydın et al. ${ }^{[17]}$ (2010) stated that there were more visits from 12:00 to 16:00 during working hours. In the literature, there are also studies reporting the rate of visits during working hours as $31.5 \% .{ }^{9}$ In our study, while the number of visits during non-working hours by Turkish citizens was found higher, 
the visits of Syrian and Afghan refugees were higher during working hours. The reasons for the high number of visits by the patients in the refugee group during working hours included factors, such as access to ED, communication, provision of the necessary medical support, and exemption from social security. Since refugees live in a different country, we think that they prefer EDs because they have difficulties adapting to the health service delivery of that country and receive better and faster health service. Turkish citizens, on the other hand, are engaged in their own business during working hours and prefer EDs during out of working hours.

Regarding the emergency level of the patients' conditions and triage levels, Şimşek et al. ${ }^{[10]}$ (2018), Gülaçtı et al. ${ }^{[1]}$ (2017), Köse et al. ${ }^{[14]}$ (2011), and Tahirbegolli et al.. ${ }^{[16]}$ (2016) reported that non-emergency patient admissions to EDs were higher (ranging from $55 \%$ to $68.5 \%$ ). According to the results of our study, nonemergency admissions of Turkish, Syrian, and Afghan patients were found to be quite high, which was consistent with the literature. Öztan et al..18] (2019) stated that the results of the refugee population and local people in terms of ED visits were similar. Diesburg-Stanwood et al. ${ }^{[19]}$ (2004) did not find any triage level differences between the visits by socioeconomic groups. ${ }^{[10]}$ According to our study, Syrian refugees presented to EDs with simpler etiologies than Turkish citizens. We thought they preferred EDs because of ease of transportation, exemption from social security, and provision of service every day and every hour of the week. Şimşek et al. ${ }^{[10]}$ (2018) did not find a relationship between gender and triage levels. Unlike the findings in the literature, we found that females presented to EDs for more serious reasons.

Gülaçtı et al. ${ }^{[1]}$ (2017) showed that refugees increased the rate of $E D$ visits and financial health burden. The cost per patient for ED visits was reported as 78.5 USD ( 1 USD $=2.87 \mathrm{TL}$ ). On the other hand, Tahirbegolli et al. ${ }^{[16]}$ (2016) showed this cost was 48 USD. Khullar et al. ${ }^{[20]}$ (2019) stated that approximately 2 billion USD was allocated to EDs for 100,000 refugees annually. Tahirbegoll et al. ${ }^{[16]}$ (2016) reported that more than one million Syrian refugees were examined in Turkey each year. Non-emergency visits are one of the main causes of ED intensity. More than one-day waiting in EDs due to the patient intensity has been reported to increase the 3-year costs of patients by 6.8 million USD. ${ }^{[21]}$ It has been stated that as the waiting time increases, hospitals end up with a loss of approximately 200 dollars per patient. ${ }^{[22]}$ According to the data of the first 10 months of 2017, family medicine centers ranked the twentieth $(0.80 \%)$ in the ranking of the number of examinations performed. ${ }^{[7]}$ According to the results of the study of Richard et al. ${ }^{[23]}$ (1995), if unnecessary visits to EDs were prevented, more than 7 billion USD would be saved annually. When non-emergency patients were referred to primary care, it was observed that the condition of $94 \%$ did not change. ${ }^{[19]}$ Gülaçtı et al..$^{[11]}$ (2017) showed that ED use increased as a result of the visits of Syrian refugees and that the additional financial burden arising from the health services of Syrian refugee patients was significant. No difference was found between nationalities in terms of per capita costs. According to the results of our study, the behavior of presenting to ED for non-emergency reasons was very high for all 3 groups.

\section{Limitations}

There were some limitations in our study. First of all, the size of the difference between the groups in our study was due to the very low proportion of the Syrian and Afghan population in our province to the general population of the province. For this reason, carrying out this single-center and retrospective study as a multi-center and prospective study will be more beneficial to the literature.

\section{CONCLUSION}

The profile of patients presenting to EDs should essentially be related to emergencies. However, due to many reasons, they have become units where unsuitable and non-emergency patients present to. This situation has led to a decrease in the attention that should be paid to real emergencies. Therefore, for the effective and appropriate use of EDs, patient characteristics should be known well, refugees should be informed about the health system after they are admitted to the country, training programs on the use of health service applications should be planned and individuals should be trained on this topic from a young age, more effective use of primary healthcare services should be ensured, EDs should be optimized for the present conditions, and ED employees should be trained, which will play an active role in solving these problems. Directing these groups to polyclinics or primary healthcare services during working hours will reduce the unnecessary burden brought on the economy in EDs.

\section{ETHICAL DECLARATIONS}

Ethics Committee Approval: The study was carried out with the permission of Tokat State Hospital Ethics Committee (Permission granted: 02.03.2020, Decision no: 04-02).

Informed Consent: All patients signed the free and informed consent form.

Referee Evaluation Process: Externally peer-reviewed.

Conflict of Interest Statement: The authors have no conflicts of interest to declare.

Financial Disclosure: The authors declared that this study has received no financial support.

Author Contributions: All of the authors declare that they have all participated in the design, execution, and analysis of the paper, and that they have approved the final version.

\section{REFERENCES}

1. Santin T, Filipi I., Preçi G. (2016). Ciò Che Ci Spezza II Cuore E Ci Trasforma In Missionarıe: Nelle Vie Della Speranza.

2. Pew Research Center. Key Facts About Refugees to the U.S. Available at http://www.pewre search.org/fact-tank/2017/01/30/key facts-about -refugees-to-the-u-s/. Accessed 13 Nov 2017 
3. United Nations High Commissioner for Refugees. Global Trends Forced Displacement in 2017

4. Suriyeli mültecilerin toplam sayısı ilk kez 4 milyonu geçti. Birleşmiş Milletler Türkiye Ofisi Resmi Web Sitesi. Available at: http://data.Unhcr. Org/Syrianrefuges/regional.

5. https://data2.unhcr.org/en/situations/syria

6. Richardson LD, Hwang U. America's Health Care Safety Net: Intact or Unraveling? SAEM Newslett, 2001; XIII(2):7

7. Sağlık Bakanlığı Kamu Hastaneleri Genel Müdürlüğü tarafından 2017 yılı Ocak-Ekim dönemi acil servislere ilişkin veriler

8. Richardson LD, Hwang U. Access to Care: A Review of the Emergency Medicine Literature. Academic Emergency Medicine, 2001; 8:1030-1036

9. Ersel M, Karcıoğlu Ö, Yanturalı S, Yürüktümen A, Sever M, Tunç MA. Bir Acil Servisin Kullanım Özellikleri ve Başvuran Hastaların Aciliyetinin Hekim ve Hasta Açısından Değerlendirilmesi. Türkiye Acil Tıp Dergisi, 2006; 6(1):2535

10. Simsek D. Ö. Triaj Sistemlerine Genel Bakış ve Türkiye'de Acil Servis Başvurularını Etkileyen Faktörlerin Lojistik Regresyon ile Belirlenmesi. Sosyal Güvence Dergisi, 2018; Yıl:7 Sayı: 13

11. Gulacti U, Lok U, Polat H. Emergency Department Visits of Syrian Refugees and the Cost of Their Healthcare.Pathogens and Global Health, 2017; Vol;111, No: 5, 219-224

12. Cevik C, Tekir Ö. Acil Servis Başvurularının Tanı Kodları, Triyaj ve SosyoDemografik Açıdan Değerlendirilmesi. Balikesir Saglik Bil Derg, 2014; Cilt:3 Sayı:2

13. Oktay C, Cete Y, Eray O, Pekdemir M, Gunerli A. Appropriateness of Emergency Department Visits in a Turkish University Hospital. Croat Med J, 2003; 44(5):585-91

14. Köse A, Köse B, Öncü MR, Tuğrul F. Bir Devlet Hastanesi Acil Servisine Başvuran Hastaların Profili ve Başvurunun Uygunluğu. Gaziantep Tıp Derg, 2011; 17(2): 57-62

15. Inncesu E. Acil Servis Sağlık Hizmetlerinde Başvuru Tekrarı Sorunu: Seydişehir Devlet Hastanesi Acil Servis Araştırması, Akademik Bakış, 2016; $0(53) ; 2$

16. Tahirbegolli B, Çavdar S, Sümer EÇ, Akdeniz SI, Vehid S. Outpatient Admissions and Hospital Costs of Syrian Refugees in A Turkish University Hospital. SaudiMed J, 2016; Vol. 37 (7)

17. Aydın T, Aydın ŞA, Köksal O, Özdemir F, Kulaç S, Bulut M. Uludağ Üniversitesi Tıp Fakültesi Hastanesi Acil Servisi'ne Başvuran Hastaların Özelliklerinin ve Acil Servis Calışmalarının Değerlendirilmesi. Akademik Acil Tıp Dergisi, 2010; 9(4):163-8

18. Öztan MO, Bolova G, Sayan A, Özdemir T, Anıl AB, Elmalı F, et al. Comparison of Syrian and Turkish Patients with Trauma Who Hospitalized in the Pediatric Surgery Department. J Pediatr Emerg Intensive Care Med, 2019; 6:30-34

19. Diesburg-Stanwood A, Scott J, Oman K, et al. Nonemergent ED Patients Referred to Community Resources After Medical Screening Examination: Characteristics, Medical Condition After 72 Hours, and Use of Follow-up Services. J Emerg Nurs, 2004; 30:312-317

20. Khullar D, Chokshi DA. Immigrant Health, Value-Based Care, and Emergency Medicaid Reform. JAMA, 2019; Volume 321, Number 10

21. Krochmal P, Riley TA. Increased Healthcare Costs Associated with ED Overcrowding. Am J Emerg Med, 1994; 12:265-266

22. Bayley MD, Schwartz JS, Shofer FS, et al. The Financial Burden of Emergency Department Congestion and Hospital Crowding for Chest Pain Patients Awaiting Admission. Ann Emerg Med, 2005; 45:110-117

23. Richard, B. Telephone Triage Cuts Costly ER Visits, The Wall Street Journal, 1995 